\title{
Hyvää vointia maidontuottajille ja eläimille
}

Marja Kallioniemi ${ }^{1}$, Kati Saarinen ${ }^{2}$, Satu Raussi ${ }^{3}$, Ahti Simola ${ }^{4}$, Eeva Pitkänen ${ }^{5}$, Hanna-Riitta Kymäläinen $^{6}$

${ }^{1}$ MTT Taloustutkimus, os. MTT Vihti, Vakolantie 55, 03400 Vihti, marja.kallioniemi@mtt.fi

${ }^{2}$ Joensuun yliopisto, os. Tutkimuspalvelu Hiisi, Valtakatu 30 A 18, 53100 Lappeenranta, kasaarin@cc.joensuu.fi

${ }^{3}$ MTT Kotieläintuotannon tutkimus, os. MTT Vihti, Vakolantie 55, 03400 Vihti, satu.raussi@mtt.fi

${ }^{4}$ Työterveyslaitos, os. Työyhteisöt ja organisaatiot, PL 486, 33101 Tampere, ahti.simola@ttl.fi

${ }^{5}$ Novetos Oy, os. Bulevardi 46, 00150 Helsinki, eeva.pitkanen@novetos.fi

${ }^{6}$ Helsingin yliopisto, agroteknologian laitos, os. PL 28, 00014 Helsingin yliopisto, hannariitta.kymalainen@helsinki.fi

\section{Tiivistelmä}

Hyvinvoiva eläinten hoitaja on motivoitunut työstään ja jaksaa huolehtia paitsi omasta, myös eläinten hyvinvoinnista. Aiemmat maatalousyrittäjien työhyvinvointia ja työkykyä koskevat tutkimustulokset ovat kuitenkin olleet huolestuttavia. Samaan aikaan yleisessä keskustelussa on alettu pohtia elintarviketuotannon vastuullisuutta ja eettisyyttä sekä tuotantoeläinten hyvinvointia. Maa- ja metsätalousministeriö onkin vuonna 2006 laatinut tuotantoeläinten hyvinvointistrategian.

Vuonna 2009 käynnistynyt tutkimushanke Maitotilan Hyvä Vointi eli "Maidontuottajien työhyvinvointi keinona edistää eläinten hyvinvointia ja yrittäjien jaksamisen tukeminen muutoksessa” pureutuu ongelmaan, miten rakennemuutoksen keskellä löydetään keinoja maatilayrittäjien jaksamisen parantamiseksi ja tuotantoeläinten hyvinvoinnin edistämiseksi.

Hankkeessa selvitetään maatilayrittäjän toimintaympäristöä, jaksamista, voimavaratekijöitä sekä hoitajan ja eläinten hyvinvoinnin välisiä yhteyksiä. Keskeisiä kysymyksiä ovat myös, millaisia muutoksia rakennemuutos on tuonut tullessaan maatiloille, onko nykyinen työympäristö tarkoituksenmukainen, ja miten uusi teknologia vaikuttaa työhön ja työolosuhteisiin. Hankkeen lopuksi toteutetaan kehittämisosa, jossa saatujen tulosten pohjalta etsitään keinoja nykytilanteen parantamiseksi.

Käytännön toimina tutkimuksessa laaditaan maatilan toimintaympäristöselvitys ja toteutetaan lomakekysely maidontuottajille. Lisäksi tehdään laadullinen tutkimus 20:llä tuotantoaan laajentaneella maitotilalla, jotka sijaitsevat Pohjois-Savossa ja Pohjois-Pohjanmaalla. Tilakäynneillä havainnoidaan työtä sekä haastatellaan ja selvitetään eläinten olosuhteita ja hyvinvointia. Kehittämisohjelmassa järjestetään työpajat, joissa työstetään kokeellisessa osassa saatuja tuloksia. Lisäksi järjestetään maatalousyrittäjille yhteisiä valmennustilaisuuksia, joissa paneudutaan hankkeen keskeisiin teemoihin kuten muutoksen hallintaan, sidosryhmäsuhteisiin ja eläinten hyvinvointiin.

Hankkeen toteuttajina ovat MTT eli Maa- ja elintarviketalouden tutkimuskeskus, Joensuun yliopisto, Työterveyslaitos ja Novetos Oy sekä vastuutahona Helsingin yliopiston agroteknologian laitos. Hanketta rahoittavat Maa- ja metsätalousministeriö (Makera), Maatalousyrittäjien eläkelaitos Mela ja MTT. Hanke jatkuu vuoden 2011 loppuun saakka.

Asiasanat: työhyvinvointi, eläinten hyvinvointi, maidontuotanto, maatila, jaksaminen 


\section{Johdanto}

Viime vuosina maidontuotantomme rakenne on muuttunut. Karjakoot sekä viljelyksessä olevat peltoalat tilaa kohti ovat kasvaneet ja uutta teknologiaa hyödynnetään aiempaa enemmän. Yrityskoon kasvu lisää yrittäjän haasteita hallita kokonaisuus, jonka yhtenä osana on omasta jaksamisesta huolehtiminen. Yrittäjän työkykyisyys, terveys ja jaksaminen ovat maatilan menestykselle keskeinen ja elintärkeä toimintaresurssi (Peltoniemi 2005).

Eläinten hyvinvoinnista on käyty kuluneina vuosina vilkasta yhteiskunnallista keskustelua. Eläinten tuotanto-olosuhteille asetettavat vaatimukset lisääntynevät jatkossa, ja hoitajan tulee perehtyä sekä useasti myös investoida eläinten hyvinvointiin. Yhteiskunnan yleinen mielipide on, että tuotantoeläinten hyvinvointiin on panostettava ja sen taso on turvattava (Tuotantoeläinten hyvinvointistrategia 2006 ja Luonnonvarainneuvoston kannanotto tuotantoeläinten hyvinvoinnista 12.06.2008). Uusien säädösten huomioon ottaminen sekä uusien menetelmien ja teknologioiden käyttö vaatii yrittäjältä jatkuvaa oppimista. Maidontuottajien päivittäiset työtehtävät ovat edelleen sitovia ja vastuullisia.

Suurin osa maatiloistamme (88 \% v. 2006) on yksityishenkilön omistuksessa (Finfood 2008), jolloin omistaja tai omistajapariskunta tekee päätökset maatilan toiminnoista ja yleensä myös työskentelee itse tilalla. Viljelijäperheen jäsenet tekivät edelleen $84 \%$ maatalous- ja puutarhatöistä vuonna 2007 (Joensuu 2008). Maatilan perhekuntaan saattaa kuulua ydinperheen lisäksi vanhuksia sekä muita lähisukulaisia. Lähipiirillä ja sosiaalisilla suhteilla on keskeinen vaikutus henkiseen hyvinvointiin. Pråhl-Ollila (1995) kuvailee, kuinka maatalousyrittäjän työ liittyy läheisesti vapaa-aikaan, perheeseen, kotiin, sukuun ja luontoon. Nämä eri elementit lomittuvat toisiinsa, joskin maatalouden murros on lisännyt maatalousyrittäjän paineita suhtautua työhön uudella tavalla. Edellä mainitussa, 1990-luvulla toteutetussa kyselytutkimuksessa viljelijöiden voimavaratekijöiksi ilmenivät maaseudun elinympäristö, puoliso, lapset ja uskonto.

Maaseudun nopea rakennemuutos, yhteisöllisyyden väheneminen (Leskinen 2004) ja perhekäsityksen muuntuminen individualistisemmiksi eli yksilön oikeuksia korostavammaksi (Katila 2000, Leskinen 2004) ovat vähentäneet maaseudun sosiaalisia verkostoja. Myös perinteinen talonpoikainen itsenäisyys on viime vuosina muuttunut, kun EU:n jäsenyys on lisännyt maatiloja koskevia säädöksiä, ehtoja, kirjanpitoa ja valvontaa.

Muutokset vaikuttavat maidontuottajien työhyvinvointiin, työssä jaksamiseen, ja peilautuvat helposti myös hoidettavien tuotantoeläinten hyvinvointiin. Jos yrittäjän fyysisessä tai henkisessä terveydessä on ongelmia, tämä alkaa näkyä helposti maatilayrityksenkin toiminnassa. Vaikeudet voivat kaatuvan dominopalikan tapaan aiheuttaa seurannaisvaikutuksena eläinten hyvinvoinnin laiminlyönnin. Hälyttävää on, että Kauppisen ym. (2008) tuoreen tutkimuksen mukaan karjatalousyrittäjät kokevat omasta jaksamisestaan huolehtimisen vaikeaksi, vaikka tietävät sen olevan välttämätön edellytys eläinten hyvälle hoidolle ja hyvinvoinnille. Hoitajan käyttäytymisellä ja ammattitaidolla on tutkimusten mukaan eniten vaikutusta eläinten hyvinvointiin kotieläintiloilla (Hemsworth ja Coleman 1998).

Tapaturmien riski voi kasvaa uupuneella työntekijällä. Samoin huolimattomuus saattaa lisääntyä aiheuttaen eläimille sekä ihmisille vaaratilanteita ja stressiä. Kotieläintiloilla eläinten laiminlyönteihin sortuneiden henkilöiden taustalla on yleensä vakavia ongelmia, jotka saattavat liittyä henkiseen tai fyysiseen kuntoon sekä mahdollisesti myös taloudellisiin ongelmiin. Ennaltaehkäisevät toimet ja avun riittävän aikaisin saaminen auttaisivat eläimiä työkseen hoitavia välttymään vakavalta työuupumukselta. Samalla vältyttäisiin eläinten olosuhteiden heikkenemiseltä ja hoidon laiminlyönniltä.

\section{Tutkimushankkeen tavoitteet}

Vuonna 2009 käynnistynyt tutkimushanke Maitotilan Hyvä Vointi eli "Maidontuottajien työhyvinvointi keinona edistää eläinten hyvinvointia ja yrittäjien jaksamisen tukeminen muutoksessa” pureutuu ongelmaan, miten rakennemuutoksen keskellä löydetään keinoja maatilayrittäjien jaksamisen parantamiseksi ja tuotantoeläinten hyvinvoinnin edistämiseksi. Hankekokonaisuuden osatekijät on esitetty kuvassa 1. 


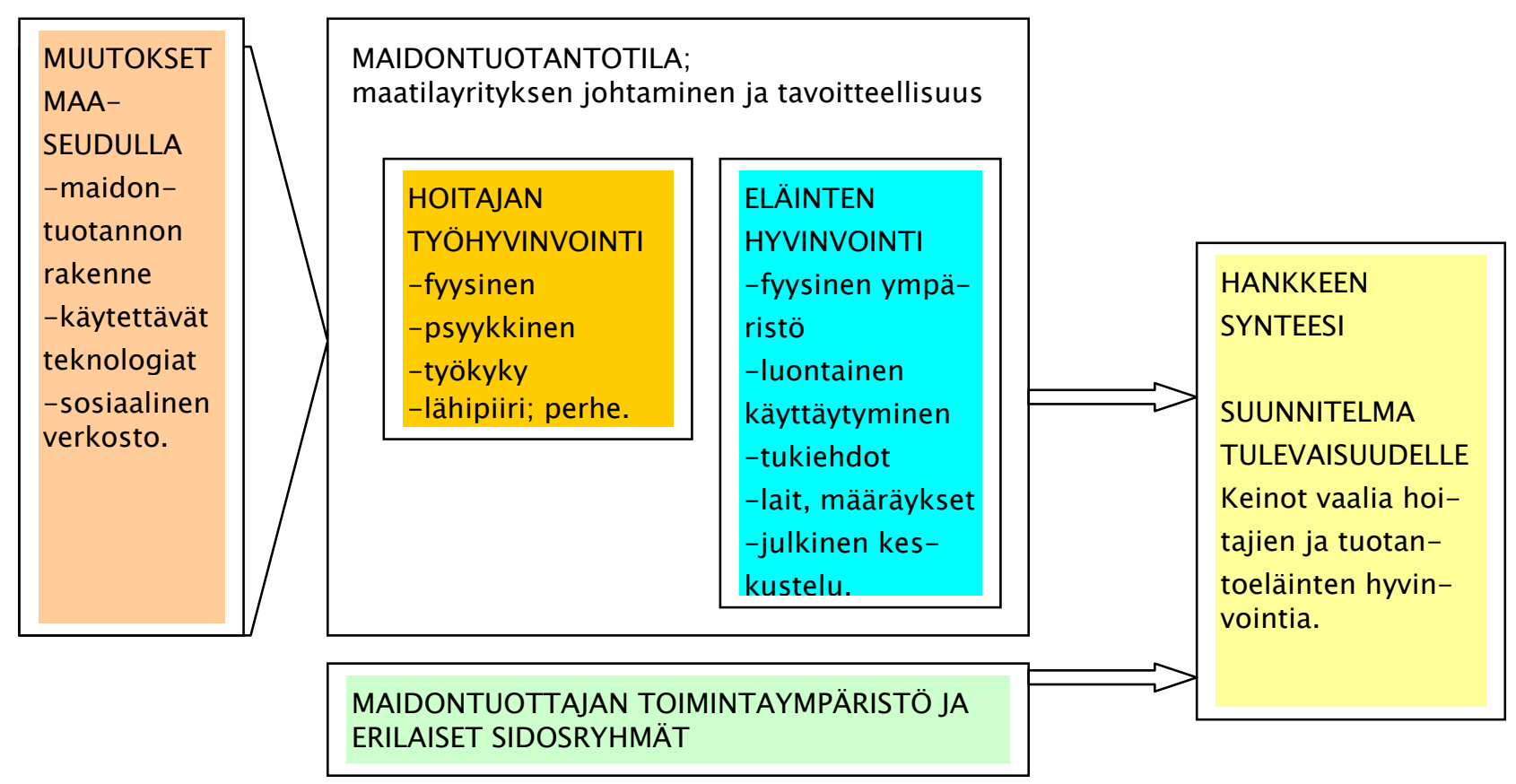

Kuva 1. Hankekokonaisuuden osatekijät.

Tutkimuksessa selvitetään

a) miten eläinten hoitajat ylläpitävät omaa jaksamistaan,

b) mitä ovat maatilayrittäjien voimavaratekijät,

c) millainen on maatilayrittäjien toimintaympäristö ja asema sidosryhmäverkostossa

d) miten maatilayrittäjät pystyvät teknisten ja taloudellisten vaatimusten sekä nopeiden muutosten keskellä huolehtimaan omasta fyysisestä ja psyykkisestä työhyvinvoinnistaan sekä eläinten hyvinvoinnista, ja miten on mahdollista kehittää omaa ammattitaitoaan uupumatta liikaa,

e) onko hoitajan työhyvinvoinnin mittareiden ja eläinten mitatun hyvinvoinnin välillä löydettävissä yhteyksiä.

\section{Tutkimushankkeen toteutus}

Hankkeen osa-alueet, joita eri menetelmillä selvitetään, on esitetty kuvassa 2. Käytännön toimina tutkimuksessa laaditaan maatilan toimintaympäristöselvitys ja toteutetaan lomakekysely maidontuottajille. Lisäksi tehdään laadullinen tutkimus 20:llä tuotantoaan laajentaneella maitotilalla, jotka sijaitsevat Pohjois-Savossa ja Pohjois-Pohjanmaalla. Tilakäynneillä havainnoidaan työtä sekä haastatellaan ja selvitetään eläinten olosuhteita ja hyvinvointia. Kehittämisohjelmassa järjestetään työpajat, joissa työstetään kokeellisessa osassa saatuja tuloksia. Lisäksi järjestetään maatalousyrittäjille yhteisiä valmennustilaisuuksia, joissa paneudutaan hankkeen keskeisiin teemoihin kuten muutoksen hallintaan, sidosryhmäsuhteisiin ja eläinten hyvinvointiin.

Hankkeen toteuttajina ovat Joensuun yliopisto, MTT eli Maa- ja elintarviketalouden tutkimuskeskus, Työterveyslaitos ja Novetos Oy sekä vastuutahona Helsingin yliopiston agroteknologian laitos. Hanketta rahoittavat Maa- ja metsätalousministeriö (Makera), Maatalousyrittäjien eläkelaitos Mela ja MTT. Hanke jatkuu vuoden 2011 loppuun saakka. 


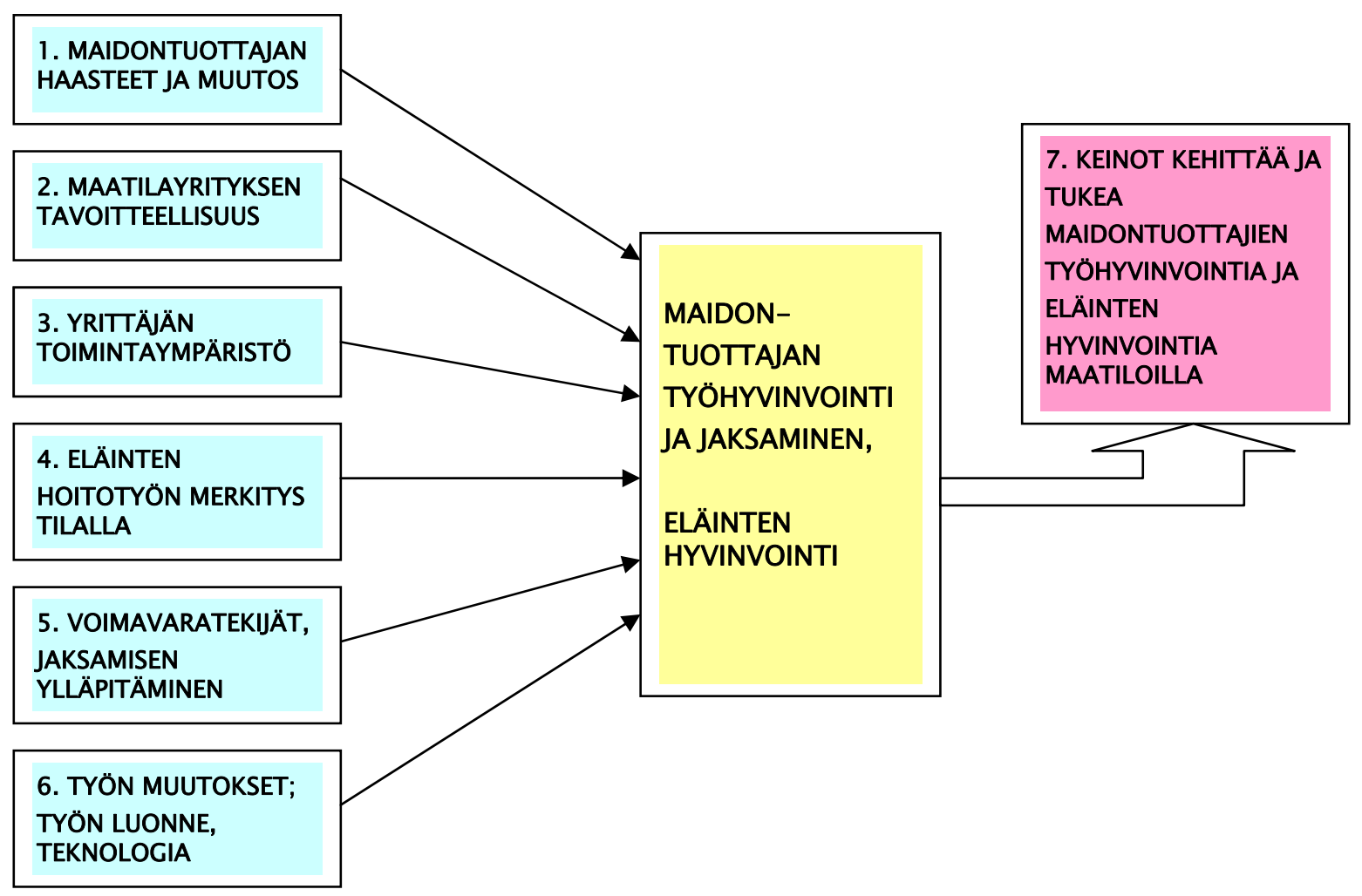

Kuva 2. Tutkimusongelmien ja -kysymysten kokonaisuus. Numerot viittaavat tutkimuskysymyksiin.

\section{Lähteet}

Finfood 2008. Maatilojen omistus. Tilastotaulukko internetissä (www-osoite: http://www.ruokatieto.fi/Suomeksi/Ruokafaktaa/Tietohaarukka). Luettu 28.5.2008.

Hemsworth, P. H., Coleman, G. J. 1998. Human-livestock interactions: The stockperson and the productivity and welfare of intensively-farmed animals. CAB International, Oxon, UK.

Joensuu P. 2008. Maatiloilla tehdään työtä 7 tuntia vuoden jokaisena päivänä. Maaseudun Tulevaisuus 16.5.2008.

Katila S. 2000. Moraalijärjestyksen rajaama tila: maanviljelijä-yrittäjäperheiden selviytymisstrategiat. Helsinki School of Economics and Business Administration, Acta Universitatis Oeconomicae Helsingiensis A-174, Helsinki. $251 \mathrm{~s}$.

Kauppinen, T. Valros, A., Raussi, S., Vesala, K. 2008. Tuotantoeläinten hyvinvointi - tuottajien asenteet ja käytännöt. Loppuraportti 10.02.2008. Helsingin yliopisto. Ruralia-instituutti. 37 sivua + 7 liitettä.

Leskinen J. 2004. Saloseudulta EU-isänäksi - lypsykarjayrittäjät muutosmurroksessa. Seurantatutkimus 1997 2001. (Dairy farmers in a period of transition. A follow-up study 1997-2001) Finnish Institute of Occupational Health, Helsinki, Työ ja ihminen, Tutkimusraportti 24.

Luonnonvarainneuvoston kannanotto tuotantoeläinten hyvinvoinnista 12.06.2008.

http://www.mmm.fi/fi/index/etusivu/ymparisto/luonnonvarainneuvosto/kannanototjalausunnot.html

Peltoniemi, A. 2005. Työllisten työkyky vuonna 2004. Työpoliittinen tutkimus. Nro 273. Työministeriö, Helsinki.

Pråhl-Ollila M. 1995. Selviytyjiä, epätietoisia ja putoajia. Nuoren viljelijäväestön erilaistuminen. Maatalousyrittäjien eläkelaitoksen julkaisuja 1/95. Espoo. 115 s.

Tuotantoeläinten hyvinvointistrategia 2006. Työryhmämuistio mmm 2006:20. Helsinki.

http://www.mmm.fi/attachments/5gtVvmZ1L/5jwHnH57g/Files/CurrentFile/tuotantoelainten_hyvinvointistrateg ia.pdf 